\title{
Effect of integrated use of lime, manure and mineral $P$ fertilizer on bread wheat (Triticum aestivum) yield, uptake and status of residual soil $P$ on acidic soils of Gozamin District, north-western Ethiopia
}

\author{
Mekonnen Asrat ${ }^{1,}$, Heluf Gebrekidan ${ }^{1}$, Markku Yli-Halla ${ }^{2}$, Bobe Bedadi ${ }^{1}$, Wakene Negassa ${ }^{3}$ \\ ${ }^{1}$ School of Natural Resources Management and Environmental Sciences, Haramaya University, Haramaya, Ethiopia \\ ${ }^{2}$ Environmental Soil Science, University of Helsinki, Helsinki, Finland \\ ${ }^{3}$ Department of Plant Soil and Microbial Sciences, Michigan State University, East Lansing, USA
}

\section{Email address:}

mek.asrat@yahoo.com (M. Asrat), helufgebrekidan@yahoo.com (H. Gebrekidan), mylihall@mappi.helsinki.fi (M. Yli-Halla), bobedadi2009@gmail.com (B. Bedadi),wakenechewaka@yahoo.co.uk (W. Negassa)

To site this article:

Mekonnen Asrat, Heluf Gebrekidan, Markku Yli-Halla, Bobe Bedadi, Wakene Negassa. Effect of Integrated Use of Lime, Manure and Mineral P Fertilizer on Bread Wheat (Triticum Aestivum) Yield, P uptake and Status of Residual Soil P on Acidic Soils of Gozamin District, North-Western Ethiopia. Agriculture, Forestry and Fisheries. Vol. 3, No. 2, 2014, pp. 76-85. doi: 10.11648/j.aff.20140302.15

\begin{abstract}
Soil acidity problem is one of the bottlenecks to improve crop production in high rainfall regions of Ethiopia in general and in Gozamin District of Amhara region in particular. The aim of this study was to examine the effects of integrated use of lime, manure and mineral $\mathrm{P}$ fertilizer on acid soils for wheat production and status of residual soil P. The treatments were factorial combinations of lime, manure and P fertilizer which were laid down in a randomized complete block design with three replications. The field study was conducted on Dystric Nitisols in the 2011 and 2012 main cropping seasons at Enerata Kebele, Gozamin District. Lime application hastened early germination while plant height was enhanced by interaction of lime and P. Most parameters were significantly $(p<0.01)$ affected by two-way interactions while three-way interactions effect increased grain and straw yield at non-significant $(\mathrm{p}>0.05)$ level. In these interactions lime rates were related in quadratic trend while manure and mineral $\mathrm{P}$ related linearly. The combined application of $5 \mathrm{t}$ manure and $2.2 \mathrm{tha} \mathrm{t}^{-1}$ lime increased grain and straw yield by $279 \%$ and $187 \%$, respectively over the control treatment through economical analysis result 515 Eth. birr (\$28) ha ${ }^{-1}$ profit obtained due to additional yield obtained. Although all treatments residual soil $\mathrm{P}$ were categorized under very low status, it has strong positive correlation $\left(\mathrm{r}^{2}=0.79\right)$ with lime application. The present study showed the combined application of $5 \mathrm{t}$ manure and $2.2 \mathrm{t} \mathrm{ha}^{-1}$ lime was found to be economical feasible to improve wheat yield and yield components and residual soil $\mathrm{P}$ of acidic soils of the study area.
\end{abstract}

Keywords: Bread Wheat Yield, Dystric Nitisols, Integrated, Lime, Manure

\section{Introduction}

Soil fertility degradation has been described as the most important constraint to food security in sub-Saharan Africa [1]. High population growth of sub-Saharan Africa led to removal of vegetation cover and continuous cultivation of lands with low nutrient replenishment results in depletion of soil nutrients. Hence, crop productivity of sub-Saharan African countries can be increased with supplemental nutrients [2]. However, the cost of fertilizers has been increasing and has reached unaffordable level to small-scale farmers [3].

The Ethiopian highlands have a great potential for crop production, contributing $95 \%$ of the cultivated land and $90 \%$ of the economic activities of the country [4]. However, the potential in most of these areas is heavily affected by soils degradation. On the other hand, the problem has been aggravated in magnitude and degree from year to year in the last three decades. Most cultivated lands of the Ethiopian highlands are prone to soil acidity due to removal of ample amount of nutrients by leaching, crop mining and runoff as compared with grazing and forest lands. A recent study also showed that soil acidity increased on cultivated land as compared with forest and grazing lands in western part of Ethiopia [5]. Moreover, continuous application of acid forming chemical fertilizers on highly weathered tropical 
soils increase soil acidity problem [6]. Rampant acidic soils covered $40.9 \%$ of Ethiopia [7] which extend from southwestern to northwestern with east-west distribution but are concentrated in the western part of the country [8]. On the other hand, highly weathered tropical soils have strong $\mathrm{P}$ sorption capacities which intensify limitation of land suitability. Therefore, these cultivated lands require integrated soil fertility management when they are put under cultivation of economic important crops.

About $24 \%$ of the Amhara National Regional State is affected by acidity while $23 \%$ of Amhara region has been severely eroded [9]. The cultivated lands of Chemoga watershed (the study area) lost about $79 \mathrm{t}^{\text {soil ha }} \mathrm{ha}^{-1}$ per year [10] which is higher than the country's $42 \mathrm{t}$ soil ha ${ }^{-1}$ in a year as in [11]. The previous studies unequivocally, revealed severity of soil related problems that can affect agricultural sustainability of the Gozamin District. Soil acidity problem has forced most farmers to grow acid tolerant crops at the expense of economically important crops or to allocated their cultivated lands to eucalyptus plantation for the last three decades. The changes in land use and cover that occurred in Chemoga watershed between 1957 and 1998 have deteriorated soil nature which makes succession of eucalyptus plantation leading to its counteracting soil acidity and nutrient deficiency problems [12].

Wheat is one of the most staple food and economically important crop in Amhara region. However, wheat productivity has been declining from year to year in northwestern Ethiopian highlands, in general and in the study area in particular mainly due to intensive soil degradation and depletion of plant nutrients. Similarly, wheat productivity in northwestern Ethiopian highlands is $1.38 \mathrm{t} \mathrm{ha}^{-1}$ (very low) as compared with $1.58 \mathrm{t} \mathrm{ha}^{-1}$ of Ethiopian highlands and $2.5 \mathrm{t} \mathrm{ha}^{-1}$ of the global productivity $[13,14]$.

Crop productivity of marginally fertile acidic soils can be improved through integrated use of soil ameliorants and fertilizers. In line with this, soil fertility management in Ethiopia has begun to shift toward integrated approach [15]. Liming of acid soils supplemented by fertilizers and small-scale irrigation under properly planned efficient water management can help to increase land use efficiency [8]. Liming increases soil $\mathrm{pH}$ and availability of $\mathrm{P}, \mathrm{Mo}$ and $\mathrm{N}$ nutrient while it reduces exchangeable acidity $[16,6]$. Similarly, application of manure on acidic soils reduces $\mathrm{Al}^{3+}$ toxicity and increases nutrient content of the soils $[17,18]$. However, application of manure should not be considered as an alternative or total substitute for lime [8]. Therefore, to improve crop yield on such soils external $\mathrm{P}$ is vital because soil $\mathrm{P}$ deficiency is a major production constraint in soils of tropical highlands [19].

Crop yield is significantly increased by integrated use of lime and fertilizer [15]. However, meager information is available about the management effects on crop yield which limits adoption of integrated fertility management in Amhara region in general and Gozamin District in particular. Therefore, generating information on the management effect on wheat yield may help to design strategies for future research and development interventions. The aim of this study was to explore effect of integrated use of lime, manure and mineral $\mathrm{P}$ fertilizer on wheat and status of residual soil $\mathrm{P}$.

\section{Materials and Methods}

\subsection{Description of the Study Site}

The experiment was conducted at Enerata Kebele, Gozamin District, northwestern Ethiopian highlands. The site is located at $10^{\circ} 23^{\prime} 43-45^{\prime \prime} \mathrm{N}$ and $37^{\circ} 44^{\prime} 29-34^{\prime \prime} \mathrm{E}$ and at altitude of 2501 masl. According to National Metrological Service Agency, the mean annual rainfall of three decades before study was $1,344 \mathrm{~mm}$ while mean, minimum and maximum air temperatures were $16.4,10.3$ and $22.5{ }^{\circ} \mathrm{C}$, respectively (Fig. 1).

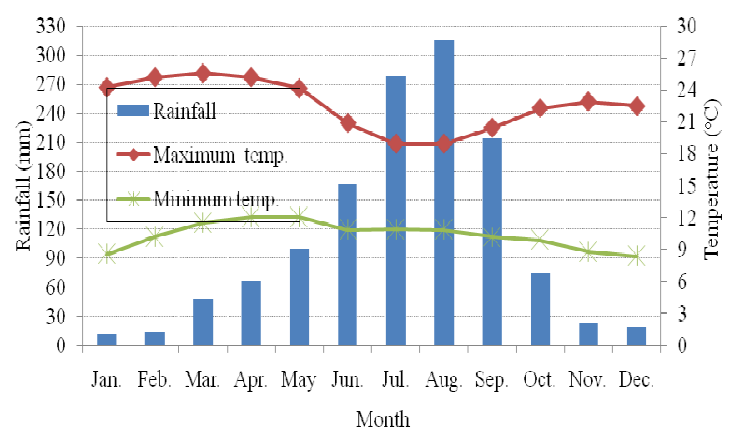

Figure 1. Mean monthly rainfall, minimum and maximum temperature of the study area based on three decades records at the Debre Maroks Meteorological Station.

The area is characterized by uni-modal rainfall pattern and its main rainfall extends from mid of June to October with peak rainfall in mid of July to end of August. The study site is classified as cool thermal zone and moist moisture regime or moist cool (M4) [20]. The study was conducted under rain-fed condition. The rainfall distribution of 2011 cropping season was optimum. However, the subsequent season's rainfall was variable with higher rainfall from July to August and lower rainfall from mid-September to mid-November. Effective rainfall of 2012 cropping season was decreased by $82 \mathrm{~mm}$ as compared to that of 2011 cropping season (Table 1).

Table 1. Metrological conditions of the cropping seasons.

\begin{tabular}{ccccc}
\hline \multirow{2}{*}{ Month } & \multicolumn{2}{c}{ Effective rainfall $(\mathbf{m m})$} & \multicolumn{2}{c}{ Mean temp. $\left({ }^{\mathbf{0}} \mathbf{C}\right)$} \\
\cline { 2 - 5 } & 2011 & 2012 & 2011 & 2012 \\
July & 146 & 160 & 15.7 & 15.5 \\
August & 154 & 158 & 15.5 & 15.5 \\
September & 153 & 137 & 15.8 & 15.5 \\
October & 36 & 33 & 19.3 & 16.8 \\
November & 82 & 1 & 16.3 & 16.2 \\
Total/mean & 571 & 489 & 16.5 & 15.9 \\
\hline
\end{tabular}

Source: National Metrological Service Agency, Bahir Dar Branch Office 


\subsection{Sampling, Analysis and Characterization of Experimental Soil, Grain, Straw, Lime and Manure}

Two composite soil samples were collected to determine selected physiochemical properties before treatment application and one composite sample pre treatment after harvest of the second season crop to evaluate effect of the treatments on status of residual soil P. From each treatment one composite wheat grain and straw samples were collected after harvesting the first season using standard procedure to evaluate the treatment effect on $\mathrm{P}$ uptake.

The collected samples were air-dried, ground and sieved with $2 \mathrm{~mm}$ sieve size. A morphological characteristic of experimental soil was described by FAO procedure [21]. Soil texture was analyzed by the hydrometer method [22]. Soil color was determined using Munsell soil color chart while bulk density was estimated from undisturbed soil samples. Porosity was determined using the following equation.

$$
f=1-P b / P s
$$

Where, $\mathrm{f}=$ total porosity, $\mathrm{Pb}$ bulk density and $\mathrm{Ps}=$ particle density $\left(2.65 \mathrm{~g} \mathrm{~cm}^{-3}\right)$.

Soil $\mathrm{pH}$ in water and $1 \mathrm{M} \mathrm{KCl}$ a solution was measured at 1:2.5 soils to water ratio and the value was read using a combined glass electrode $\mathrm{pH}$ meter. Exchangeable acidity was determined saturating the soil samples with $1 \mathrm{M} \mathrm{KCl}$ solution and titrating with $0.01 \mathrm{M} \mathrm{NaOH}$ described as in [23]. Exchangeable Al was determined from aqueous solutions extracted by $1 \mathrm{M} \mathrm{KCl}$ and $\mathrm{NaF}$ and titrated with $0.01 \mathrm{M} \mathrm{HCl}$

Exchangeable bases ( $\mathrm{Ca}, \mathrm{Mg}, \mathrm{Na}$ and $\mathrm{K}$ ) were extracted with $1 \mathrm{M} \mathrm{NH} \mathrm{NH}_{4} \mathrm{OAc}$ at $\mathrm{pH} 7$ and then $\mathrm{Ca}$ and $\mathrm{Mg}$ were determined by atomic absorption spectrophotometer, while $\mathrm{K}$ and $\mathrm{Na}$ were determined using flame photometry. Cation exchange capacity was determined by extracting the soil by $1 \mathrm{M}$ NH4OAc at $7 \mathrm{pH}$; while the adsorbed ammonium ions in soil were displaced with $\mathrm{NaCl}$. Then the ammonium liberated from the distillation was titrated using $0.1 \mathrm{M}$ $\mathrm{NaOH}$ for $\mathrm{CEC}$ determination. Effective cation exchange capacity was calculated as the sum of exchangeable basic cations and $\mathrm{Al}$ [24]. Soil total $\mathrm{N}$ and organic carbon were determined at using dry combustion method in Vario MAX elemental apparatus. Available P was extracted by Mehlich solution after shaking for $5 \mathrm{~min}$ on a reciprocating shaker according to Mehlich No. 3 method [25] and then quantified colorimetrically with spectrometer. Plant tissue's $\mathrm{P}$ content was determined as in [22]. Wheat grain and straw $\mathrm{P}$ uptake were determined by multiplying $\mathrm{P}$ concentrations of each plant part by their respective dry matter weights.

The study was conducted on Dystri-HaplicNitisols. The experimental field has not received lime or/and $\mathrm{P}$ fertilizer before this study. The soil was clay in texture and developed from intensively weathered basalt parent material. It has low bulk density. The soil was very strongly acidic [26]. The net negative charge of the soil as identified by $\Delta \mathrm{pH}=\mathrm{pH}\left(\mathrm{H}_{2} \mathrm{O}\right)-\mathrm{pH}(\mathrm{KCl})$ equation was 0.82 . Soil colloids have great potential in weather-able acidic cations [27]. The soil is medium in cation exchange capacity and the soil mineralogical family classification, based on a ratio of CEC - 7 to clay was 0.29 and grouped under kaolinite clay or mixed mineralogical family [28]. It has low $\mathrm{Ca}$ and $\mathrm{Na}$, very low available $\mathrm{P}$ and medium total $\mathrm{N}$ [29]. Selected soil physicochemical properties of the study site determined pre-planting are presented in Table 2 .

Table 2. Selected soil physicochemical properties before planting.

\begin{tabular}{lcc}
\hline Soil properties & Unit & Value \\
\hline Sand & $\%$ & 41.0 \\
Silt & $\%$ & 15.0 \\
Clay & $\%$ & 44.0 \\
Textural class & - & Clay \\
Bulk density & $\mathrm{g} \mathrm{cm}^{-3}$ & 1.17 \\
Porosity (f) & $\%$ & 56.0 \\
pH 1:2.5 (H $\left.{ }_{2} \mathrm{O}\right)$ & & 4.62 \\
pH 1:2.5 (KCl solution) & & 3.80 \\
Organic carbon & $\%$ & 1.63 \\
Total N & $\%$ & 0.17 \\
Available P & $\mathrm{mg} \mathrm{kg}^{-1}$ & 7.79 \\
Exchangeable acid & $\mathrm{cmol}_{(+)} \mathrm{kg}^{-1}$ & 1.75 \\
Exchangeable Al & $\mathrm{cmol}_{(+)} \mathrm{kg}^{-1}$ & 1.20 \\
Exchangeable Ca & $\mathrm{cmol}_{(+)} \mathrm{kg}^{-1}$ & 5.13 \\
Exchangeable Mg & $\mathrm{cmol}_{(+)} \mathrm{kg}^{-1}$ & 2.88 \\
Exchangeable K & $\mathrm{cmol}_{(+)} \mathrm{kg}^{-1}$ & 0.8 \\
Exchangeable Na & $\mathrm{cmol}_{(+)} \mathrm{kg}^{-1}$ & 0.2 \\
Total exchangeable bases & $\mathrm{cmol}_{(+)} \mathrm{kg}^{-1}$ & 9.01 \\
Cation exchange capacity (CEC) & $\mathrm{cmol}_{(+)} \mathrm{kg}^{-1}$ & 19.95 \\
Effective Cation Exchange Capacity (ECEC) & $\mathrm{cmol}_{(+)} \mathrm{kg}^{-1}$ & 10.21 \\
Base Saturation & $\%$ & 45 \\
\hline
\end{tabular}

One composite sample of the liming material was prepared in each season. The lime purity was estimated by thoroughly mixing at adjusted moisture content of $2 \mathrm{~g}$ of Dejen lime in $50 \mathrm{ml}$ of $1 \mathrm{M} \mathrm{HCl}$ and $70 \mathrm{ml}$ of deionized water solution for an hour until it stopped bubbling which was then mildly heated on hot plate for 45 minutes. The mixed solution was transferred into $500 \mathrm{ml}$ volume flask and filled with deionized water. Then $25 \mathrm{ml}$ of the mixed solution was taken and 2-3 drops of Tashiro's indicator added to it which was then titrated by $0.1 \mathrm{M} \mathrm{NaOH}$ until the red colour of the indicator disappeared. Fineness factor of Dejen lime as estimated from percentage of lime that passed through 20,60, 80 and 100 mesh sieves were 98.92, $48.44,24.97$ and $21.71 \%$, respectively. Its relative neutralizing value in the first year application was determined by multiplying the lime fineness factor (LFF) with its purity. Accordingly, the lime material was calcitic material with moisture content of $1.0562 \%$. Dejen lime has purity of 0.91 and fineness factor of 0.52 . Therefore, in the first year application its relative neutralizing value (NV) (effective calcium carbonate equivalent) was 0.47 .

The field lime requirement was estimated based as in [30] through exchangeable acidity, permissible acid saturation percentage for wheat cultivation (PASP), effective cation exchange capacity (ECEC) and lime requirement factor 
values, accordingly the predetermined rates during the experimental set up were 0, 2.2 and 3.3.t ha ${ }^{-1}$ lime.

In each cropping season, two composite manure samples were collected from decomposed manure for the determination of its moisture, total $\mathrm{N}$ and available $\mathrm{P}$ content. Moisture content of the manure was estimated through oven-drying at $105{ }^{\circ} \mathrm{C}$ for 24 hours. Total $\mathrm{N}$ and available $\mathrm{P}$ content of the manure were determined through wet digestion and Olsen method [31], respectively. The manure had mean moisture content of $31 \%$, total $\mathrm{N} 1.2 \%$ and available $\mathrm{P}$ of $0.46 \%\left(4.6 \mathrm{~g} \mathrm{~kg}^{-1}\right)$.

\subsection{Treatment and Experimental Design}

The experiment treatments consisted of three levels of manures $\left(0,5\right.$ and $\left.10 \mathrm{tha}^{-1}\right)$, mineral $\mathrm{P}$ fertilizer $(0,20$ and $30 \mathrm{~kg} \mathrm{P} \mathrm{ha}{ }^{-1}$ applied as triple superphosphate) and lime (0, 2.2 and $\left.3.3 \mathrm{t} \mathrm{ha}^{-1}\right)$. The treatments were arranged in factorial combination and replicated three times which were laid out in randomized complete block design (RCBD).

\subsection{Field Management}

The field was ploughed three times with local conventional oxen driven practices followed by manual seed-bed preparation and laid out according to experimental scheme. Dejen lime was broadcasted and thoroughly mixed into soil 50 days before wheat planting. Manure was decomposed under shade for two months and incorporated into soil 20 days before planting. The whole doses of mineral $\mathrm{P}$ fertilizer were applied in band at planting. Bread wheat (Triticum aestivum L) variety ETBW-4621 (Kulkulo) was used as test crop which was hand drilled at $150 \mathrm{~kg} \mathrm{ha}^{-1}$ rate on July 21 and 24 of 2011 and 2012 cropping seasons, respectively. Bread wheat was planted on gross plot of $2 \mathrm{~m} \times 1.25 \mathrm{~m}\left(2.5 \mathrm{~m}^{2}\right)$ with $20 \mathrm{~cm}$ inter row spacing and the net plot size was $0.6 \mathrm{~m}^{2}$. All recommended cultural practices of wheat production were adopted for the management of the experiment.

\subsection{Data Collection}

All plant data collected from crop emergence to harvest were treated as growth parameters. Growth parameters were days to emergence, heading and maturity, number of tillers, plant height, spike length and kernels per spike. However, thousand seeds and hectoliter weights, harvest index and economical yields were considered as yield parameters. Days to emergence and heading were recorded when $50 \%$ of the crop emerged and headed, respectively while days to physiological maturity was measured when $90 \%$ of the crop was matured.

Number of tillers was counted at late tillering stage (40-45 days after planting) from randomly sampled plants at $0.5 \mathrm{~m}$ row length of the net plot. Plant height, spike length and kernels per spike were measured from ten randomly sampled plants at $90 \%$ physiological maturity. Plant height was measured from the ground level to the tip of spike excluding awns. Similarly, spike length was measured from the base to the tip of spike by excluding the awns. Grain yield was estimated by adjusting moisture content to $12.5 \%$. The economic analysis was carried out by considering estimated prices of lime, manure and mineral $\mathrm{P}$ fertilizer during the application season while value of bread wheat grain at harvesting season. Accordingly, the prices of manure, lime and wheat were $500(\$ 28), 1,400(\$ 78), 7,500$ (\$ 417) Eth. birr per ton, respectively while mineral $\mathrm{P}$ fertilizer price was 102.33 Eth. birr per kg P (\$ 5.7).

\subsection{Statistical Analysis}

The data were subjected to analysis of variance by following the standard procedure [32] then analyzed using Statistical Analysis System SAS software version 9.1 [33]. Significant mean of the treatments were delineated by Duncan's Multiple Range test (DMRT) comparison at $\mathrm{p}<$ 0.01 or $\mathrm{p}<0.05$. Correlation analysis was carried between the parameters to determine magnitude and degree of their relation.

\section{Results and Discussion}

\subsection{The Crop Parameter Response}

The response of most growth and yield parameters of the crop were affected by cropping season due to the variability of rainfall in 2012 season (Table 3). In the subsequent season, delayed germination, early maturity, short height and low number of kernels per spike of wheat were recorded as compared to that of the 2011 cropping season. Moreover, in 2012 cropping season grain and straw yield decreased by 29 and $36 \%$, respectively.

Table 3. Analysis of variance (ANOVA) for bread wheat growth and yield parameters.

\begin{tabular}{|c|c|c|c|c|c|c|c|c|c|}
\hline \multirow[b]{2}{*}{ Parameter } & \multicolumn{8}{|c|}{ Sources of variations mean squares with significance level } & \multirow{2}{*}{$\begin{array}{l}\text { CV } \\
(\%)\end{array}$} \\
\hline & $\mathrm{L}(2)$ & M (2) & $P(2)$ & $\mathrm{L} * \mathrm{M}(4)$ & $\mathrm{L} * \mathrm{P}(4)$ & $\mathrm{M} * \mathrm{P}(4)$ & $\begin{array}{c}\mathrm{L} * \mathrm{M} * \mathrm{P} \\
(8)\end{array}$ & $\begin{array}{c}\text { Error } \\
(96) \\
\end{array}$ & \\
\hline Days to emerge & $2.117^{*}$ & $0.673^{\mathrm{ns}}$ & $0.117 \mathrm{~ns}$ & $0.302^{\text {ns }}$ & $0.247^{\mathrm{ns}}$ & $0.886^{\mathrm{ns}}$ & $0.28^{\text {ns }}$ & 0.439 & 11.53 \\
\hline No. tillers & $69.57^{\mathrm{ns}}$ & $479.6^{* *}$ & $93.17^{\mathrm{ns}}$ & $77.04^{\mathrm{ns}}$ & $65.41^{\text {ns }}$ & $65.24^{\mathrm{ns}}$ & $56.7^{\mathrm{ns}}$ & 46.52 & 16.77 \\
\hline Days to heading & $14.19^{*}$ & $19.34^{* *}$ & $86.67^{* *}$ & $2.47^{\mathrm{ns}}$ & $2.77^{\mathrm{ns}}$ & $1.87^{\mathrm{ns}}$ & $1.3^{\mathrm{ns}}$ & 3.02 & 2.41 \\
\hline Days to mature & $0.35^{\mathrm{ns}}$ & $5.57^{\mathrm{ns}}$ & $4.24^{\mathrm{ns}}$ & $0.31^{\mathrm{ns}}$ & $10.7^{*}$ & $1.51^{\mathrm{ns}}$ & $2.46^{\mathrm{ns}}$ & 3.96 & 1.59 \\
\hline Plant height $(\mathrm{cm})$ & $371.7^{* *}$ & $331.2^{* *}$ & $1558.2^{* *}$ & $19.35^{\mathrm{ns}}$ & $66.77^{*}$ & $22.62^{\mathrm{ns}}$ & $17.0^{\mathrm{ns}}$ & 19.29 & 6.69 \\
\hline Spike length $(\mathrm{cm})$ & $4.52^{* *}$ & $2.86^{*}$ & $19.38^{* *}$ & $1.72^{*}$ & $2.28^{* *}$ & $0.32^{\mathrm{ns}}$ & $0.29^{\mathrm{ns}}$ & 0.60 & 12.3 \\
\hline Kernels per spike & $5.44^{\mathrm{ns}}$ & $22.52^{\mathrm{ns}}$ & $369.6^{* *}$ & $46.12^{\mathrm{ns}}$ & $24.21^{\mathrm{ns}}$ & $22.95^{\text {ns }}$ & $10.4^{\mathrm{ns}}$ & 21.72 & 16.69 \\
\hline
\end{tabular}




\begin{tabular}{|c|c|c|c|c|c|c|c|c|c|}
\hline \multirow[b]{2}{*}{ Parameter } & \multicolumn{8}{|c|}{ Sources of variations mean squares with significance level } & \multirow[b]{2}{*}{$\begin{array}{l}\text { CV } \\
(\%)\end{array}$} \\
\hline & $\mathrm{L}(2)$ & M (2) & $\mathrm{P}(2)$ & $\mathrm{L} * \mathrm{M}(4)$ & $\mathrm{L} * \mathrm{P}(4)$ & $\mathrm{M} * \mathrm{P}(4)$ & $\begin{array}{c}\mathrm{L} * \mathrm{M} * \mathrm{P} \\
\quad(8)\end{array}$ & $\begin{array}{c}\text { Error } \\
(96)\end{array}$ & \\
\hline Thousand seeds weight & $6.17^{\mathrm{ns}}$ & $181.9^{* *}$ & $7.74^{\mathrm{ns}-}$ & $2.71^{\mathrm{ns}}$ & $4.99^{\text {ns }}$ & $5.8^{\text {ns }}$ & $0.774^{\mathrm{ns}}$ & 2.546 & 4.8 \\
\hline Hectoliter weight & $158.5^{\mathrm{ns}}$ & $54.34^{\mathrm{ns}}$ & $7.3^{\mathrm{ns}}$ & $224.78^{*}$ & $181.14^{\mathrm{ns}}$ & $194.3^{\mathrm{ns}}$ & $68.5^{\mathrm{ns}}$ & 82.62 & 11.13 \\
\hline Grain yield $\left(t \mathrm{ha}^{-1}\right)$ & $9.76^{* *}$ & $10.29^{* *}$ & $10.84^{* *}$ & $0.96^{* *}$ & $0.02^{\mathrm{ns}}$ & $0.538^{* *}$ & $0.24^{\mathrm{ns}}$ & 0.126 & 17.36 \\
\hline Straw yield $\left(\mathrm{t} \mathrm{ha}^{-1}\right)$ & $14.56^{* *}$ & $13.74^{* *}$ & $18.21^{* *}$ & $1.137^{* *}$ & $0.21^{\mathrm{ns}}$ & $0.93^{*}$ & $0.28^{\mathrm{ns}}$ & 0.27 & 17.52 \\
\hline Biomass yield $\left(\mathrm{t} \mathrm{a}^{-1}\right)$ & $48.17^{* *}$ & $47.81^{* *}$ & $57.03^{* *}$ & $4.136^{* *}$ & $0.33^{\text {ns }}$ & $2.85^{* *}$ & $1.02^{\mathrm{ns}}$ & 0.7 & 16.68 \\
\hline Harvest index & $0.008^{* *}$ & $0.01^{* *}$ & $0.004^{*}$ & $0.005^{* *}$ & $0.001^{\mathrm{ns}}$ & $0.00004^{\mathrm{ns}}$ & $0.0006^{\mathrm{ns}}$ & 0.001 & 7.46 \\
\hline
\end{tabular}

\subsubsection{Wheat Growth}

Most growth parameters were significantly affected by lime, manure and $\mathrm{P}$ application. However, days to maturity, plant height and spike length were significantly influenced by interaction of lime and P (Table 3 ). Wheat emerged between 5 and 7 days of planting and days to emergence were significantly affected by $2.2 \mathrm{t} \mathrm{ha}^{-1}$ lime. Lime hastened early emergence of wheat. Liming reduce $\mathrm{Al}$ concentration thus increase the availability of certain nutrient thereby improving plant growth. Total root length of plant restricted at lower $\mathrm{pH}$, and thus the unamended soil showed reduced root length as compared with lime-amended soil [34].

The number of tillers per $\mathrm{m}^{2}$ was in ranges between 132 and 354, being significantly $(p<0.01)$ increased by application of manure. Manure improves physicochemical properties of soils thereby enhancing water infiltration and root penetration $[35,36]$ and thus promoting plant tillering. On the other hand, manure amendment in acidic soils increases soil $\mathrm{pH}$, mineral $\mathrm{N}$, available $\mathrm{P}, \mathrm{K}$ and $\mathrm{Ca}[18,37]$ The number of tillers was affected by $\mathrm{N}$ rate [14, 38]. High $\mathrm{N}$ rate increased the number of tillers by $11-15 \%$ over the control. The crop reached to heading within ranges of 69 to 78 days after planting. Lime, manure and $\mathrm{P}$ applications were affected the number of days to heading (Table 3 ).

Two-way interaction of lime and $\mathrm{P}$ showed significant ( $\mathrm{p}$ $<0.05$ ) response to days to maturity (Table 3 ). On these treatments, early maturity of the crop was promoted at zero level of one factor and with increase in the rate of the other factor. Therefore, early maturities of non-limed treatments were hastened with $\mathrm{P}$ rates while early maturities of non-P applied treatments were hastened through liming (Table 4). Plant growth affected by $\mathrm{P}$ availability and $\mathrm{P}$ deficient crop delayed in maturity. These results are line with the reports of other researchers. For instance [39] reported that acidic soils adsorbed $70-90 \%$ of an applied $\mathrm{P}$ into various low soluble $\mathrm{P}$ compounds without giving any immediate contribution to crop growth, thus acidic sensitive and low acid tolerant crops usually delayed in maturity. Similarly, phosphorus deficient rice was delayed by 10-12 days to reach maturity [40]. However, liming reduces $\mathrm{P}$ sorption capacity of acidic soil thereby increasing $\mathrm{P}$ availabilities of native soil and fertilizer, consequently it enhances early maturity [41, 42]. In contrast, on plots that received both lime and mineral $\mathrm{P}$ fertilizer were delayed in days of maturity can probably be associated with the $\mathrm{P}$ adsorbed by high lime rate (Table 4).
Table 4. Lime and P interaction effect of on maturity days.

\begin{tabular}{cccc}
\hline Lime (t ha & \multicolumn{3}{c}{$\mathbf{k g ~ P ~ h a}^{-1}$} \\
& 0 & 20 & 30 \\
\hline 0 & $126.06^{\mathrm{b}}$ & $125.39^{\mathrm{ab}}$ & $124.83^{\mathrm{ab}}$ \\
2.2 & $124.88^{\mathrm{ab}}$ & $125.56^{\mathrm{ab}}$ & $125.78^{\mathrm{ab}}$ \\
3.3 & $124.5^{\mathrm{a}}$ & $126.11^{\mathrm{b}}$ & $126.06^{\mathrm{b}}$ \\
\hline
\end{tabular}

Interaction means within rows and columns with the same letter are not significantly different at $\mathrm{p}<0.01$

Interaction of lime and mineral $\mathrm{P}$ fertilizer showed significant $(\mathrm{p}<0.05)$ response to plant height (Table 3 and 5). In line with this, heights of okra plant (Abelmoschus esculentus L.) were increased by application of $500 \mathrm{~kg}$ lime and $10 \mathrm{~kg} \mathrm{P} \mathrm{ha}^{-1}$ [43] besides groundnut height significantly increased by integrated application of $3.7 \mathrm{t}$ lime and $49 \mathrm{~kg}$ $\mathrm{P}$ ha $^{-1}$ [44]. Longer wheat height was obtained with combined application of $\mathrm{P}$ and $2.2 \mathrm{tha}^{-1}$ lime as compared with $3.3 \mathrm{t} \mathrm{ha}^{-1}$ combinations. Phosphorus application increased crop height; however, crop height per unit $\mathrm{P}$ was decreased with $\mathrm{P}$ rate (Table 5). Low rate fertilization induces sharp plant growth but without increasing nutrient concentration of the tissue; however, marginal applications probably induce nutrient concentration increment of tissue rather than physical growth.

Table 5. Main and interaction of lime and P effects on plant height (cm).

\begin{tabular}{|c|c|c|c|c|}
\hline \multirow{2}{*}{$\begin{array}{l}\text { Lime }(t \\
\left.h^{-1}\right)\end{array}$} & \multicolumn{3}{|c|}{ kg $P h^{-1}$} & \multirow{2}{*}{ *Lime } \\
\hline & 0 & 20 & 30 & \\
\hline 0 & $54.56^{\mathrm{e}}$ & $66.21^{b c}$ & $68.02^{\mathrm{abc}}$ & $62.93^{\mathrm{C}}$ \\
\hline 2.2 & $64.22^{\mathrm{c}}$ & $69.43^{\mathrm{ab}}$ & $70.86^{\mathrm{a}}$ & $68.17^{\mathrm{A}}$ \\
\hline 3.3 & $59.68^{\mathrm{d}}$ & $68.38^{\mathrm{ab}}$ & $69.37^{\mathrm{ab}}$ & $65.81^{\mathrm{B}}$ \\
\hline$* \mathrm{P}$ & $59.49^{\mathrm{B}}$ & $68.0^{\mathrm{A}}$ & $69.42^{\mathrm{A}}$ & \\
\hline
\end{tabular}

Interaction mean within rows and columns with the same letter are not significantly different at $\mathrm{p}<0.01$, lower case superscripted $=$ significance of two-way interaction, upper case superscripted = significance of main effect, $*=$ main effect mean

Spike lengths ranged between 8.4 and $3.0 \mathrm{~cm}$ with a mean of $6.3 \mathrm{~cm}$. It was significantly affected by two-way interactions of lime (lime and manure; lime and P) (Table 3). Interaction effects of lime and manure, lime and $\mathrm{P}$ were significant at $\mathrm{p}<0.01$ and $\mathrm{p}<0.05$, respectively to spike length. Spike lengths of non-limed combinations increased with rates of manure or $\mathrm{P}$, in contrary, spike length of zero manure or $\mathrm{P}$ combinations increased through lime rate (Table 6). Each spike on average consisted of 28 kernels. Application of $20 \mathrm{~kg} \mathrm{P} \mathrm{ha}{ }^{-1}$ increased number of kernels by 
$15 \%$ against the control treatment. However, $\mathrm{P}$ had no effects on number of kernels [44].

\subsubsection{Wheat Yield}

Most parameters were significantly affected by two-way interactions of manure (lime and manure; $\mathrm{P}$ and manure) (Table 3). Manure and $\mathrm{P}$ combinations were linearly related to the response of most parameters while lime combinations were related in quadratic trend. Mean weight of thousand wheat seeds was $33.27 \mathrm{~g}$. Seeds weight significantly increased by application of $10 \mathrm{tha}^{-1}$ manure, it showed $11 \%$ more weight as compared to the control treatment's seeds weight. In line with this, application of $\mathrm{P}$ and lime did not significantly affect seeds weight [14, 45-47]. An application of manure improved $\mathrm{N}$ content of soils through its decomposition and creating favorable environmental conditions for the occurrence of organisms. The crop mean grain hectoliter weight was $81.7 \mathrm{~kg} \mathrm{hl}^{-1}$. Well-filled and plump wheat grains were obtained on lime and manure applied plots as compared to the other treatments.

Table 6. Main and two-way interactions effects of lime, manure and P on spike length (cm).

\begin{tabular}{|c|c|c|c|c|c|c|c|}
\hline \multirow{2}{*}{ Lime h ha $^{-1}$} & \multicolumn{4}{|c|}{ Manure $t$ ha $^{-1}$} & \multicolumn{2}{|c|}{ P kg ha ${ }^{-1}$} & \multirow{2}{*}{ *Lime } \\
\hline & 0 & 5 & 10 & 0 & 20 & 30 & \\
\hline 0 & $5.69^{d}$ & $5.94^{\mathrm{cd}}$ & $6.33^{\mathrm{abcd}}$ & $4.84^{\mathrm{C}}$ & $6.49^{\mathrm{AB}}$ & $6.63^{A}$ & $5.99^{\mathrm{B}}$ \\
\hline 2.2 & $6.03^{\mathrm{cd}}$ & $6.88^{\mathrm{a}}$ & $6.77^{\mathrm{ab}}$ & $6.11^{\mathrm{AB}}$ & $6.79^{\mathrm{A}}$ & $6.78^{\mathrm{A}}$ & $6.56^{\mathrm{A}}$ \\
\hline 3.3 & $6.47^{\mathrm{abc}}$ & $6.14^{\mathrm{bcd}}$ & $6.47^{\mathrm{abc}}$ & $5.88^{\mathrm{B}}$ & $6.73^{\mathrm{A}}$ & $6.47^{\mathrm{AB}}$ & $6.36^{\mathrm{AB}}$ \\
\hline * Manure and $\mathrm{P}$ & $6.06^{\mathrm{B}}$ & $6.32^{\mathrm{AB}}$ & $6.52^{\mathrm{A}}$ & $5.61^{\mathrm{B}}$ & $6.67^{\mathrm{A}}$ & $6.63^{\mathrm{A}}$ & \\
\hline
\end{tabular}

Interaction mean within rows or columns with the same letter are not significantly different at $\mathrm{p}<0.01$, lower case superscripted $=$ significance of interaction of manure and lime, upper case superscripted $=$ significance of interaction of lime and $\mathrm{P}$ and individual main effects, $*=$ main effect mean

Table 7. Main and two-way interactions of manure effects on grain yield ( tha $\left.^{-1}\right)$

\begin{tabular}{|c|c|c|c|c|c|c|c|}
\hline \multirow{2}{*}{ Manure $\mathbf{t ~ h a}^{-1}$} & \multicolumn{3}{|c|}{ Lime $\mathrm{tha}^{-1}$} & \multicolumn{3}{|c|}{$\mathrm{P} \mathrm{kg} \mathrm{ha}^{-1}$} & \multirow{2}{*}{ *Manure } \\
\hline & 0 & 2.2 & 3.3 & 0 & 20 & 30 & \\
\hline 0 & $0.898^{d}$ & $1.98^{\mathrm{bc}}$ & $1.787^{\mathrm{c}}$ & $1.191^{\mathrm{D}}$ & $1.654^{\mathrm{BC}}$ & $1.820^{\mathrm{B}}$ & $1.56^{\mathrm{C}}$ \\
\hline 5 & $1.741^{\mathrm{c}}$ & $2.689^{\mathrm{a}}$ & $2.17^{\mathrm{b}}$ & $1.466^{\mathrm{CD}}$ & $2.501^{\mathrm{A}}$ & $2.619^{A}$ & $2.2^{\mathrm{B}}$ \\
\hline 10 & $2.215^{\mathrm{b}}$ & $2.736^{\mathrm{a}}$ & $2.212^{\mathrm{b}}$ & $1.958^{\mathrm{B}}$ & $2.515^{\mathrm{A}}$ & $2.704^{\mathrm{A}}$ & $2.39^{\mathrm{A}}$ \\
\hline * Lime and $\mathrm{P}$ & $1.618^{\mathrm{C}}$ & $2.468^{\mathrm{A}}$ & $2.056^{\mathrm{B}}$ & $1.538^{\mathrm{B}}$ & $2.223^{\mathrm{A}}$ & $2.381^{\mathrm{A}}$ & \\
\hline
\end{tabular}

All denoted figures are the same as Table 6

The mean grain yield was $2.05 \mathrm{t} \mathrm{ha}^{-1}$ while mean maximum and minimum grain yields were 3.13 and $0.71 \mathrm{t}$ $\mathrm{ha}^{-1}$, respectively. Both main effects and two-way interactions of manure significantly $(p<0.01)$ affected the grain yield. In line with this, it has been reported that in highly weathered tropical soils, wheat grain yield improved by application of lime and fertilizers [48]. Sole application of $3.7 \mathrm{tha}^{-1}$ lime has also been reported to have increased wheat grain yield by twice of the control treatment [49].

Integrated liming and fertilization through manure and mineral $\mathrm{P}$ fertilizer management brought more grain yield than their respective main effects. Significant mean of the interaction was obtained on combined $5 \mathrm{t} \mathrm{ha}^{-1}$ manure and $2.2 \mathrm{t} \mathrm{ha}^{-1}$ lime treatment which brought 0.26 to $0.85 \mathrm{t} \mathrm{ha}^{-1}$ more grain yield than respective individual effect.

Lime rates were quadratically increased grain yield while the yield increased linearly by manure rates. Application of $2.2 \mathrm{t} \mathrm{ha}^{-1}$ lime in combination with fertilizer's treatments gave more grain yields than $3.3 \mathrm{t} \mathrm{ha}^{-1}$ combinations (Table 7). Even though the three-way interactions were not-significant to wheat yield, combined application of $2.2 \mathrm{t}$ lime, $5 \mathrm{t} \mathrm{ha}^{-1}$ manure and $30 \mathrm{~kg} \mathrm{P} \mathrm{ha}{ }^{-1}$ showed the highest grain and straw yield. The statistical analysis revealed that integrated application of $5 \mathrm{t}$ manure and $2.2 \mathrm{t} \mathrm{ha}^{-1}$ lime gave $2.7 \mathrm{tha}^{-1}$ grain yield with additional yield of $2 \mathrm{t} \mathrm{ha}^{-1}(279 \%)$ over the control treatment. Meanwhile the combined application of $5 \mathrm{t}$ manure and $20 \mathrm{~kg} \mathrm{P} \mathrm{ha}^{-1}$ gave $2.5 \mathrm{t} \mathrm{ha}^{-1}$ grain yield with additional yield of $1.8 \mathrm{t} \mathrm{ha}^{-1}$ (252\%) over the control treatment. According to the crop grain and straw yield response, the combined application of $5 \mathrm{t}$ manure and $2.2 \mathrm{t} \mathrm{ha}^{-1}$ lime applications in Dystric Nitisols of northwestern Ethiopian improved crop yield.

\subsubsection{Economic Analysis for Grain Yield}

Marginal rate of return of the combined $2.2 \mathrm{t}$ lime and $5 \mathrm{t}$ $\mathrm{ha}^{-1}$ manure treatment was 51.50 which gave net benefit of 515 Eth. birr (\$28) ha ${ }^{-1}$ as compared with combined $5 \mathrm{t}$ manure and $20 \mathrm{~kg} \mathrm{P} \mathrm{ha}{ }^{-1}$ due to $70 \mathrm{~kg} \mathrm{ha}^{-1}$ grain yield increment (Table 8).

Table 8. Economical analysis of two-way interactions of manure effects for bread wheat grain yield.

\begin{tabular}{|c|c|c|c|c|c|c|c|c|}
\hline \multirow{2}{*}{$\begin{array}{c}\text { Treatment } \\
\text { (combination) }\end{array}$} & \multicolumn{4}{|c|}{ Cost of the input (Eth, birr) } & \multirow{2}{*}{$\begin{array}{l}\text { Grain yield } \\
\qquad\left(\mathrm{t} \mathrm{ha}^{-1}\right)\end{array}$} & \multirow{2}{*}{$\begin{array}{c}\text { Total value of } \\
\text { grain (Eth. } \\
\text { birr) }\end{array}$} & \multirow{2}{*}{$\begin{array}{l}\text { Net return } \\
\text { (Eth. birr) }\end{array}$} & \multirow{2}{*}{$\begin{array}{l}\text { Marginal } \\
\text { rate of } \\
\text { return (\%) }\end{array}$} \\
\hline & Manure (M) & Lime (L) & mineral $\mathrm{P}(\mathrm{P})$ & Total & & & & \\
\hline $\mathrm{M}_{10 \mathrm{tha}^{-1} \times \mathrm{P}_{30 \mathrm{kgha}^{-1}}}$ & 5,000 & - & 3,070 & 8,070 & 2.704 & $20,280.00$ & $12,210.00$ & \\
\hline 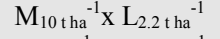 & 5,000 & 3,080 & - & 8,080 & 2.736 & $20,520.00$ & $12,444.00$ & 2340 \\
\hline 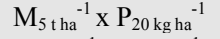 & 2,500 & - & 3,070 & 5,570 & 2.619 & $19,642.50$ & $14,072.50$ & \\
\hline $\mathrm{M}_{5 \text { tha }}{ }^{-1} \times \mathrm{L}_{2.2 \mathrm{tha}^{-1}}$ & 2,500 & 3,080 & - & 5,580 & 2.689 & $20,167.50$ & $14,587.50$ & 5150 \\
\hline
\end{tabular}


Table 9. Main and two way interactions of manure effects on straw yield ( $\left.t \mathrm{~h}^{-1}\right)$.

\begin{tabular}{|c|c|c|c|c|c|c|c|}
\hline \multirow{2}{*}{ Manure $\left(\mathrm{t} \mathrm{ha}^{-1}\right)$} & \multicolumn{3}{|c|}{ Lime $\left(\mathrm{t} \mathrm{ha}^{-1}\right)$} & \multicolumn{3}{|c|}{$P\left(\mathrm{~kg} \mathrm{ha}^{-1}\right)$} & \multirow{2}{*}{ *Manure } \\
\hline & 0 & 2.2 & 3.3 & 0 & 20 & 30 & \\
\hline 0 & $1.666^{\mathrm{e}}$ & $2.897^{\mathrm{bcd}}$ & $2.628^{\mathrm{cd}}$ & $1.909^{\mathrm{D}}$ & $2.501^{\mathrm{CD}}$ & $2.781^{\mathrm{BC}}$ & $2.397^{\mathrm{B}}$ \\
\hline 5 & $2.509^{\mathrm{d}}$ & $3.777^{\mathrm{a}}$ & $3.076^{\mathrm{bc}}$ & $2.173^{\mathrm{CD}}$ & $3.44^{\mathrm{AB}}$ & $3.75^{\mathrm{A}}$ & $3.121^{\mathrm{A}}$ \\
\hline 10 & $3.137^{\mathrm{b}}$ & $3.754^{\mathrm{a}}$ & $3.212^{\mathrm{b}}$ & $2.864^{\mathrm{BC}}$ & $3.452^{\mathrm{AB}}$ & $3.787^{\mathrm{A}}$ & $3.368^{\mathrm{A}}$ \\
\hline * Lime and $\mathrm{P}$ & $2.438^{\mathrm{C}}$ & $3.476^{\mathrm{A}}$ & $2.972^{\mathrm{B}}$ & $2.316^{\mathrm{C}}$ & $3.131^{\mathrm{B}}$ & $3.439^{\mathrm{A}}$ & \\
\hline
\end{tabular}

All denoted figures are the same as Table 6

Like the grain yield, the straw yield was significantly affected by two-way interactions of manure (Table 3 and 9). This in agreement with another report where combined application of lime and mineral $\mathrm{P}$ fertilizer significantly increasing straw yield of rice [50]. The combined application of $5 \mathrm{t}$ manure and $2.2 \mathrm{t} \mathrm{lime}^{-1}$ gave $3.8 \mathrm{t}$ straw ha ${ }^{-1}$ which increased the yield by $2.5 \mathrm{t} \mathrm{ha}^{-1}(187 \%)$ over the control. Meanwhile the combined application of 5 $\mathrm{t}$ manure and $20 \mathrm{~kg} \mathrm{P} \mathrm{ha}^{-1}$ application gave $3.4 \mathrm{t}$ straw ha ${ }^{-1}$ which increased the yield by $2.1 \mathrm{t} \mathrm{ha}^{-1}(162 \%)$ over the control treatment.

Table 10. Wheat P uptake $\left(\mathrm{kg} \mathrm{ha}^{-1}\right)$ of the treatments.

\begin{tabular}{|c|c|c|c|c|}
\hline \multirow{2}{*}{$\begin{array}{l}\text { Lime } \\
\text { t ha }^{-1}\end{array}$} & \multirow{2}{*}{$\begin{array}{c}\text { Manure } \\
\text { t ha }^{-1}\end{array}$} & \multicolumn{3}{|c|}{ kg P ha ${ }^{-1}$ and uptake } \\
\hline & & 0 & 20 & 30 \\
\hline 0 & 0 & 1.44 & 1.91 & 3.28 \\
\hline 0 & 5 & 2.53 & 4.60 & 7.58 \\
\hline 0 & 10 & 5.6 & 8.61 & 8.96 \\
\hline 2.2 & 0 & 7.03 & 6.37 & 11.86 \\
\hline 2.2 & 5 & 8.46 & 10.00 & 12.4 \\
\hline 2.2 & 10 & 14.67 & 16.09 & 17.74 \\
\hline 3.3 & 0 & 7.20 & 10.45 & 10.45 \\
\hline 3.3 & 5 & 7.31 & 14.96 & 14.46 \\
\hline 3.3 & 10 & 11.73 & 12.73 & 12.95 \\
\hline
\end{tabular}

The highest biomass was $7.59 \mathrm{t} \mathrm{ha}^{-1}$ which was obtained with combined application of $2.2 \mathrm{t}$ lime, $5 \mathrm{t}$ manure and 30 $\mathrm{kg} \mathrm{P} \mathrm{ha}{ }^{-1}$ whereas the lowest biomass yield was $2.02 \mathrm{tha}^{-1}$ in control treatment. Similarly, biomass yield was significantly $(\mathrm{p}<0.01)$ affected by two-way interactions of manure (Table 3). The combined application of $5 \mathrm{t}$ manure and $2.2 \mathrm{t} \mathrm{ha}^{-1}$ lime treatment increased the biomass by $152 \%$ over the control treatment while the combined application of $5 \mathrm{t}$ manure and $30 \mathrm{~kg} \mathrm{P} \mathrm{ha}^{-1}$ increased the yield by $105 \%$ over the control yield.

The highest wheat harvest index was obtained on combined $2.2 \mathrm{t}$ lime and $10 \mathrm{tha}^{-1}$ manure treatment, the harvest index increased by $19 \%$ against the control treatment. The harvest index of wheat observed in the present study was in the range of 0.35 to 0.44 that agreed with similar findings elsewhere [51]. The interaction of lime and manure significantly affected wheat harvest index.

Most parameters were correlated positively $\left(r^{2}=0.24\right.$ to 0.95 ) with each other except days to emergence and heading. However, number of tillers, plant height, spike length, kernels per spike, thousand seeds weight, grain and straw yield correlations followed similar trends.

\subsubsection{Nutrient P Uptake}

Wheat $\mathrm{P}$ uptake was influenced by the application of lime and manure. Crop grown in acidic soils showed more $\mathrm{P}$ uptake in response to liming than manure application. Phosphorus uptake values were recorded in the ranges between 1.44 and $17.74 \mathrm{~kg}$ ha- 1 . Wheat absorbed high $\mathrm{P}$ on combined $2.2 \mathrm{t}$ lime, $10 \mathrm{t}$ ha-1 manure and $20-30 \mathrm{~kg}$ P ha- 1 treatments (Table 10). Liming increased soil $\mathrm{pH}$ as a consequent fixed $\mathrm{P}$ released to plant absorption. Hence, slight decrease in $\mathrm{P}$ uptake has been observed at high rate of liming (3.3 t ha-1). In line with this, liming increased $\mathrm{P}$ uptake of bread wheat by $91-93 \%$ over the control treatment [52]. On the other hand, manure increased $\mathrm{P}$ availability through decomposition and by having liming effect. However, P applications non-significantly increased wheat $\mathrm{P}$ uptake in acidic soils.

\subsection{Status of Residual Soil P}

Before planting, soil $\mathrm{P}$ was $7.79 \mathrm{mg} \mathrm{kg}^{-1}\left(13.67 \mathrm{~kg} \mathrm{P} \mathrm{ha}^{-1}\right.$ in $15 \mathrm{~cm}$ soil depth), however, at the post-harvest of 2012 season the treatments residual P records were between 2.58 and $29.69 \mathrm{~kg} \mathrm{ha}^{-1}$ or 1.47 and $16.92 \mathrm{mg} \mathrm{kg}^{-1}$. The lowest residual soil $\mathrm{P}$ was recovered from combined zero lime and manure treatment, whereas the highest on high manure and lime (Table 11).

Table 11. Soil P in $15 \mathrm{~cm}$ soil depth at the post-harvest of 2012 season.

\begin{tabular}{|c|c|c|c|c|}
\hline \multirow{2}{*}{$\begin{array}{l}\text { Lime } \\
\text { t ha }\end{array}$} & \multirow{2}{*}{$\begin{array}{c}\text { Manure } \\
\mathbf{t ~ h a}^{-1}\end{array}$} & \multicolumn{3}{|c|}{ kg $P h^{-1}$ and residual soil $P\left(\mathrm{~kg} \mathrm{ha}^{-1}\right)$} \\
\hline & & 0 & 20 & 30 \\
\hline 0 & 0 & 9.55 & 2.58 & 4.33 \\
\hline 0 & 5 & 6.46 & 12.81 & 14.39 \\
\hline 0 & 10 & 9.55 & 18.25 & 16.16 \\
\hline 2.2 & 0 & 16.74 & 14.99 & 10.34 \\
\hline 2.2 & 5 & 15.11 & 22.10 & 19.16 \\
\hline 2.2 & 10 & 10.42 & 22.04 & 14.78 \\
\hline 3.3 & 0 & 26.75 & 26.75 & 21.39 \\
\hline 3.3 & 5 & 19.13 & 27.85 & 25.47 \\
\hline 3.3 & 10 & 29.69 & 27.01 & 27.69 \\
\hline
\end{tabular}

Residual soil $\mathrm{P}$ of lime received treatments were increased by 55 to $60 \%$ while manure received treatments were increased by 8 to $22 \%$ as compared with non-treated plots (Table 11). Residual soil P was positively correlated $\left(\mathrm{r}^{2}=0.79^{* *}\right)$ to lime. In line with this, as in $[41,42]$ reported liming of acidic soils reduce the $\mathrm{P}$ sorption thus increasing its availabilities. However, over all residual soil $\mathrm{P}$ of the treatments were categorized under very low status.

\section{Conclusions}

Most wheat growth and yield parameters were 
significantly $(p<0.01)$ affected with the interaction of lime and manure, lime and $\mathrm{P}$ and interaction of manure and $\mathrm{P}$. However, the crop economical yields were significantly affected by interaction of manure and lime; manure and $\mathrm{P}$. The combined application of $5 \mathrm{t}$ manure and $2.2 \mathrm{t}$ lime ha ${ }^{-1}$ increased wheat grain and straw yield by 2 and $2.5 \mathrm{t} \mathrm{ha}^{-1}$ over the control treatment, respectively. Meanwhile, the combined application of $5 \mathrm{t}$ manure and $20 \mathrm{~kg} \mathrm{P} \mathrm{ha}^{-1}$ increased grain and straw yields by 1.8 and $2.1 \mathrm{t} \mathrm{ha}^{-1}$ over the control treatment, respectively. On the other hand, the combined application of $5 \mathrm{t}$ manure and $2.2 \mathrm{t} \mathrm{ha}^{-1}$ lime gave more net benefit of 515.50 Eth. birr (\$27.6) as compared with the combined application of $5 \mathrm{t}$ manure and $30 \mathrm{~kg} \mathrm{P}$ $\mathrm{ha}^{-1}$ since the small-scale farmers in the study area have more access to lime than mineral $\mathrm{P}$ fertilizer. Wheat absorbed $10.29 \mathrm{~kg} \mathrm{ha}^{-1} \mathrm{P}$ on combined $5 \mathrm{t}$ manure and $2.2 \mathrm{t}$ $\mathrm{ha}^{-1}$ lime treatment while slightly lower $\left(9.85 \mathrm{~kg} \mathrm{ha}^{-1}\right)$ in combined $5 \mathrm{t}$ manure and $30 \mathrm{~kg} \mathrm{P} \mathrm{ha}^{-1}$ application. Although soil $\mathrm{P}$ was very low in the study areas the combined application of lime and manure increased available $\mathrm{P}$ that attributed to high $\mathrm{P}$ desorbing capacity of lime. Overall, the combined application of $5 \mathrm{t}$ manure and $2.2 \mathrm{t}^{\mathrm{time}} \mathrm{ha}^{-1}$ has improved wheat yield on marginally fertile acidic soils of northwestern Ethiopian highlands.

\section{Acknowledgments}

We acknowledge the Ministry of Education for Federal Democratic Republic of Ethiopia to the financial grant. Our especial thanks extended to the University of Helsinki School of Natural Resources Management and Environmental Sciences for lime analysis and part of the soil analyses.

\section{References}

[1] World Bank. Natural resource degradation in Sub Saharan Africa. Restoration of soil fertility. A concept paper and action plan. World Bank, Washington, USA. 1996.

[2] C. Marc, S. Abebe and H. Mitiku. Farmers' knowledge of soil fertility and local management strategies in Tigray, Ethiopia. Managing Africa's Soils, 2000, 10: pp 1-30.

[3] A. Maatman, M. Wopereis, K. Debrah and J. Groot. From Thousands to Millions: Accelerating Agricultural Intensification and Economic Growth in Sub-Saharan Africa. In: Bationo (Ed.), Springer. Advances in Integrated Soil Fertility Management in Sub-Saharan Africa: Challenges and Opportunities, 2007, pp 75-84.

[4] Food and Agriculture Organization. Ethiopian Highland Reclamation Study, Ethiopia. Final Report (Volume I and II). Food and Agricultural Organization of the United Nations, 1986, Rome, Italy.

[5] C. Achalu, G. Heluf, K. Kibebew and T. Abi. Response of barley to liming of acid soils collected from different land use systems of western Oromia, Ethiopia. Journal of Biodiversity and Environmental Sciences, 2012, 2(5): pp 37-49.
[6] A. Nekesa. Effect of Minjingu phosphate rock and agricultural lime in relation to maize, groundnut and soybean yields on acid soils of western Kenya. MSc Thesis, Moi University, Eldoret, Kenya. 2007.

[7] H. Schlede. Distribution of acid soils and liming materials in Ethiopia. Ethiopian Institute of Geological Surveys, Ministry of Mines and Energy. Addis Ababa, Ethiopia. 1989.

[8] A. Mesfin. Nature and management of acid soils in Ethiopia, 2007. www.eiar.gov.et/ Soil/ soils acid.pdf.

[9] Amhara National Regional State's Investment office. Potential survey, identification of opportunities and preparations of projects profiles and feasibility studies, part one potential assessment. Unpublished soil survey study report by Development Studies Association (DSA) and Shawel Consult International (SCI). 2006.

[10] B. Woldeamlak and S. Geert. Assessment of soil erosion in cultivated field using a survey methodology for rill in the Chemoga watershed, Ethiopia. Unpublished doctoral dissertation, Wageningen University, The Netherlands. 2003.

[11] H. Hurni. Land degradation, famines and resource scenarios in Ethiopia. In: Pimentel, D. (Ed). World Soil Erosion and Conservation. Cambridge University Press, pp 27-62. 1993.

[12] B. Woldeamlak and L. Stroonsijder. Effects of agro-ecological land use succession on soil properties in Chemoga watershed, Blue Nile basin, Ethiopia. Geoderma, 2003, 111: pp 85-98.

[13] G. Ashenafi. Triticale production in Ethiopia- its impact on food security and poverty alleviation in the Amhara Region, Doctoral thesis, Kassel University, Germany. 2008. urn:nbn:de 0002-4115no. 2007:03.

[14] A. Worku Effects of nitrogen and seed rates on yield and yield components of bread wheat (Triticum aestivum L.) in Yelmana Densa District, northwestern Ethiopia. MSc. Thesis, Haramaya University, Haramaya, Ethiopia. 2008.

[15] International Food Policy Research Institute. Fertilizer and soil fertility potential in Ethiopia, Constraints and opportunities for enhancing the system, working paper, July, 2010. www.ifpri.org. 2010.

[16] E. Caires, L. Alleoni, M. Cambri and G. Barth. Surface application of lime for crop grain production under a no-till system. American Society of Agronomy J., 2005, 97: pp791-798.

[17] K. Hati, A. Swarup, D. Singh, A. Misra and P. Ghos. Long-term continuous cropping, fertilization and manure effects on physical properties and organic carbon content of a sandy loam soil. Australian Journal of Soil Research, 2006, 44: pp 487-495.

[18] J. Whalen, C. Chang, G. Clayton and J. Carefoot. Cattle manure amendments can increase $\mathrm{pH}$ of acid soils. Soil Science Society of America Journal, 2000, 64: pp 962-966.

[19] R. Onwonga, J. Lelei, B. Freyer, J. Friedel, S. Mwonga and P. Wandahwa. Low cost techniques for enhancing $\mathrm{N}$ and $\mathrm{P}$ availability and maize (Zea mays $L$.) performance on acid soils. World Journal of Agricultural Sciences, 2008, 4: pp 862-873.

[20] Ministry of Agriculture and Rural Development. Agro-Ecological Zones of Ethiopia. Addis Ababa, Ethiopia. 2005. 
[21] Food and Agriculture Organization (FAO). Guidelines for Soil Description. Food and Agriculture Organization of the United Nations, 2006, Rome, Italy.

[22] S. Sahlemedhin and B. Taye. Procedure for soil and plant analysis. National Soil Research Centre, Ethiopian Agricultural Research Organization, Addis Ababa, Ethiopia. 2000 .

[23] D. Rowell. Soil Science: Method and Applications. Addison, Wesley, England: Longman Scientific and Technical, Longman Group UK Limited. 1994.

[24] United States Department of Agriculture Natural Resources Conservation Services (USDANRCS). Soil Survey Laboratory Information Manual. National soil Survey Laboratory, Soil Survey Investigation Report No. 45 Version 1, pp 1-305. 1995.

[25] M. Mehlich. Mehlich 3 soil test extractant: a modification of the Mehlich 2 extractant. Communications in Soil Science and Plant Analysis, 1984, 15: pp 1409-1416.

[26] R. Bruce and G. Rayment. Analytical methods and interpretations used by the Agricultural Chemistry Branch for Soil and Land Use Surveys. Queens land Department of Primary Industries. 1982.

[27] T. Barauah and H. Barthakur. A Text Book of Soil Analyses. Vikas Publishing House Pvt. Ltd. New Delhi, India. 1997, pp 334.

[28] National Soil Survey Laboratory Staff. Principles and procedures for using soil survey laboratory data. USDASCS, Lincoln, NE. 1983

[29] P. Hazelton and B. Murphy. Interpreting Soil Test Results: What do all the numbers mean? $2^{\text {nd }}(\mathrm{Ed})$. NSW (New South Wales Department) Department of Natural Resources, Collingwood, Australia: CSIRO Publishing, 2007. http://www.publish. csiro.au.

[30] B. Taye, M. Zebene and E. Abayneh. Laboratory procedure for the determination of lime requirement and calcium carbonate content in lime. National Soil Research Center Ethiopian Institute of Agricultural Research, unpublished laboratory manual. 2007.

[31] S. Olsen, C. Cole, F. Watanab and L. Dean. Estimation of available phosphorous in soils by extraction with sodium bicarbonate. USA, Circular 939: pp 1-19. 1954.

[32] Gomez and A. Gomez. Statistical Procedure for Agricultural Research $2^{\text {nd }}$ (Ed.). Wiley, A., Inter-Science Publication, New York, USA. 680. 1984

[33] SAS Institute Inc.SAS User's Guide, Statistics version 9.1 (Ed). SAS Inst. Cary, NC, USA. 2002.

[34] R. Haling, R. Simpson, R. Culvenor, H. Lambers and A. Richardson, Effect of soil acidity, soil strength and macropores on root growth and morphology of perennial grass species differing in acid-soil resistance. Blackwell Publishing Ltd, Plant Cell and Environment, 2011, 34, pp 444-456. doi: 10.1111/j.1365-3040.2010.02254.x.

[35] T. Butler and J. Muir. Dairy manure compost improves soil and increases tall wheatgrass. Agronomy J., 2006, 98: pp 1090-1096.

[36] G. McAndrews, M. Liebman, C. Cambardella and T. Richard. Residual effects of composted and fresh solid swine (Sus scrofa L.) manure on soybean (Glycine max L.) growth and yield. Agronomy J., 2006, 98: pp 873-882.

[37] F. Naramabuye, R. Haynes and A. Modi, Cattle manure and grass residues as liming materials, in a semi-subsistence farming system. Agriculture, Ecosystems and Environment, 2008, 124: pp 136-141.doi:10.1016/j.agee.2007.08.005.

[38] H. Melesse. Response of bread wheat (Triticum aestivum L.) varieties to $\mathrm{N}$ and $\mathrm{P}$ fertilizer rates in Ofla District, southern Tigray, Ethiopia. MSc Thesis, Haramaya University, Haramaya, Ethiopia. 2007.

[39] I. Holford. Soil phosphorus measurements and its uptake by plants. Aust. J. Soil Res., 1977, 35: pp 227-239.

[40] N. Fageria, N. Slaton and V. Baligar. Nutrient management for improving lowland rice productivity and sustainability. Adv. Agronomy, 2003, 80: pp 63-152.

[41] M. Osundwa, J. Okalebo, W. Ngetich, J. Ochuodho, C. Othieno, B. Langat and V. Omenyo. Influence of agricultural lime on soil properties and wheat (Triticum aestivum L.) yield on acidic soils of Uasin Gishu County, Kenya. American Journal of Experimental Agriculture, 2013, 3(4): pp 806-823.

[42] J. White, M. Bell and N. Marzies. Effect of subsoil acidity treatments on the chemical properties of Ferrosol. Proceeding agronomy Conference, 10-15 September 2006, Australia. 2006.

[43] F. Oluwatoyinbo, M. Akande and J. Adediran. Response of okra (Abelmoschus esculentus) to lime and phosphorus fertilization in an acid soil. World Journal of Agricultural Sciences, 2005, 1(2): pp 178-183.

[44] R. Ranjit. Response of groundnut genotypes to lime and phosphorus levels in coastal alluvial soil of north Karnataka. MSc Thesis, Dharwad University, India. 2005.

[45] K. Endalkachew. Effects of rates and methods of phosphorus placement on residual soil $\mathrm{P}$ yield and $\mathrm{P}$ uptake of wheat in Nitosols of Kulumsa area, Arsi zone. MSc Thesis, Alemaya University, Haramaya, Ethiopia. 2006.

[46] N. Fageria and A. Santos. Yield physiology of dry bean. $J$. Plant Nutrition, 31: 983-1004. 2008.

[47] J. Nakagawa, I. Imaizumi and C. Rosseto. Effects of some phosphorus sources and of liming on groundnut seed quality. Pesquisa Agropecuaria Brasileria, 1990, 25(4): pp 505-512.

[48] N. Fageria and V. Baligar. Fertility management of tropical acid soils for sustainable crop production. In: Rengel, Z. (Ed.) Handbook of Soil Acidity, Marcel Dekker, New York, USA. 2003. pp 359-385.

[49] D. Guangdi, P. Rajinder, P. John and R. Keith. A financial analysis of lime application in a long-term agronomic experiment on the south-western slopes of New South Wales. Crop and Pasture Science, 2009, 61: pp 12-23.

[50] A. Mongia, N. Singh and A. Guha. Response of rice to liming and $\mathrm{P}$ application in acid soils of South Andaman. Journal of the Indian Society of Soil Science, 46(4): pp 697-700. 1998.

[51] D. Hussins and W. Pan. Nitrogen efficiency components analysis: an evaluation of cropping system difference in productivity. Agronomy Journal, 85: pp 898-905. 1993. 
[52] K. Abreha, G. Heluf, M. Tekalign, and T. Kindie. Wheat crop response to liming materials and $\mathrm{N}$ and $\mathrm{P}$ fertilizers in acidic soils of Tsegede highlands, northern Ethiopia.
Agriculture, Forestry and Fisheries. 2, 3: pp 126-135. 2013doi: 10.11648/aff.20130203.12. 